\title{
PERANAN SISTEM INFORMASI MANAJEMEN DALAM PENGAMBILAN KEPUTUSAN SUATU LEMBAGA ATAU ORGANISASI
}

\author{
Decision making proccess in Management Information System \\ Nazla Fitria \\ Prodi Sistem Informasi, Fakultas Sains dan Teknologi, Universitas Islam Negeri \\ Sumatera Utara \\ nazlafitria16@gmail.com
}

\begin{abstract}
Abstrak
Dalam Lembaga atau Organisasi banyak manfaat suatu sistem informasi bila digunakan sebaik mungkin. Keputusan yang baik akan ada jika terdapat informasi yang baik. Sistem Informasi memiliki pengetahuan dalam memecahkan masalah melalui alternatif pemecahannya sehingga dibutuhkan dalam pengambilan keputusan yang logis. Sistem Informasi hanya berperan sebagai alat bantu yang akan mempermudah manajemen suatu organisasi dalam mengambil keputusan, namun tidak untuk menggantinya. Karena manajemen dari suatu perusahaan akan memiliki Decision Support System (DSS) yang akan membantu manajer dalam mengambil keputusan.
\end{abstract}

Kata kunci : Sistem, Sistem Informasi, Organisasi, DSS, Keputusan

\section{PENDAHULUAN}

Perkembangan Ilmu dan teknologi telah banyak mengubah gaya hidup dan pandangan orang-orang terutama masyarakat di Indonesia dalam menjalani kehidupan. Dewasa ini, informasi dianggap telah mampu mengguncangkan berbagai bidang kehidupan manusia. Baik di bidang Ekonomi, Sosial, Budaya, maupun Ilmu Pengetahuan. Karena hal tersebut telah membuat perkembangan yang membawa era baru dari bidang-bidang tersebut.

Akan tetapi, seiring dengan perkembangan Informasi di tengah masyarakat itu tidak diimbangi dengan peningkatan Sumber Daya Manusia. Padahal seorang yang berkualitas adalah penentu dari keberhasilan tujuan sebuah Lembaga atau Organisasi. 
Informasi sangat penting di dalam kehidupan manusia sekarang. Perkembangan zaman yang mana teknologi pun semakin canggih maka berkembang pula sebuah istilah Sistem Informasi Manajemen. Sudah jelas dari Namanya, sistem ini berperan penting dalam Lembaga atau Organisasi.

Manfaat SIM dalam Lembaga atau Organisasi sangat banyak jika dijabarkan, namun salah satu manfaatnya ialah di bidang Sumber Daya Manusia (SDM). Setiap kegiatan yang dilakukan didalam Manajemen Sumber Daya Manusia akan berjalan mulus jika memakai Sistem Informasi dengan tepat dan valid.

\section{STUDI LITERATUR}

\section{Konsep Dasar Sistem}

Sistem ialah suatu komponen elemen yang saling bekerja sama hingga membentuk satu kesatuan untuk mencapai suatu tujuan tertentu dan jika salah satu unsur ada yang tidak berfungsi ataupun hilang, maka gabungan dari semua komponen tersebut tidak dapat lagi disebut sistem.

Setiap komponen atau elemen sistem mempunyai sub sistem yang memiliki sifat dari sistem untuk menjalankan atau mengerjakan suatu proses sistem secara keseluruhan. Penghubung antara satu sub sistem dengan sub sistem yang lainnya berupa media yang biasa disebut penghubung (interface). Dengan penghubung sub sistem ini dapat membuat sub sistem dapat berinteraksi dengan sub sistem yang lainnya hingga membentuk kesatuan. Melalui penghubung keluaran (output) untuk sub sistem akan menjadi masukan (input) sub sistem yang lain.

Suatu sistem pastinya memiliki sasaran (objective) atau tujuan (goal) yang akan sangat menentukan masukan dan keluaran yang dibutuhkan dan dihasilkan oleh sistem.

\section{Konsep Dasar Informasi}

Informasi merupakan sekumpulan data yang telah di olah dan menghasilkan bentuk yang lebih valid serta lebih berguna untuk menambahkan pengetahuan dan pengertian bagi si penerima informasi tersebut yang digunakan untuk 
pengambilan keputusan. Suatu informasi bersumber dari data, yaitu bisa disebut juga dengan fakta (kejadian yang nyata ataupun kesatuan yang nyata).

Data masih berbentuk mentah dan belum mendapat banyak penjelasan, sehingga akan diolah lebih lanjut melalui suatu model yang akhirnya akan menghasilkan informasi. Data itu akan ditangkap sebagai input, diproses lagi melalui suatu model dan seterusnya membentuk sebuah siklus.

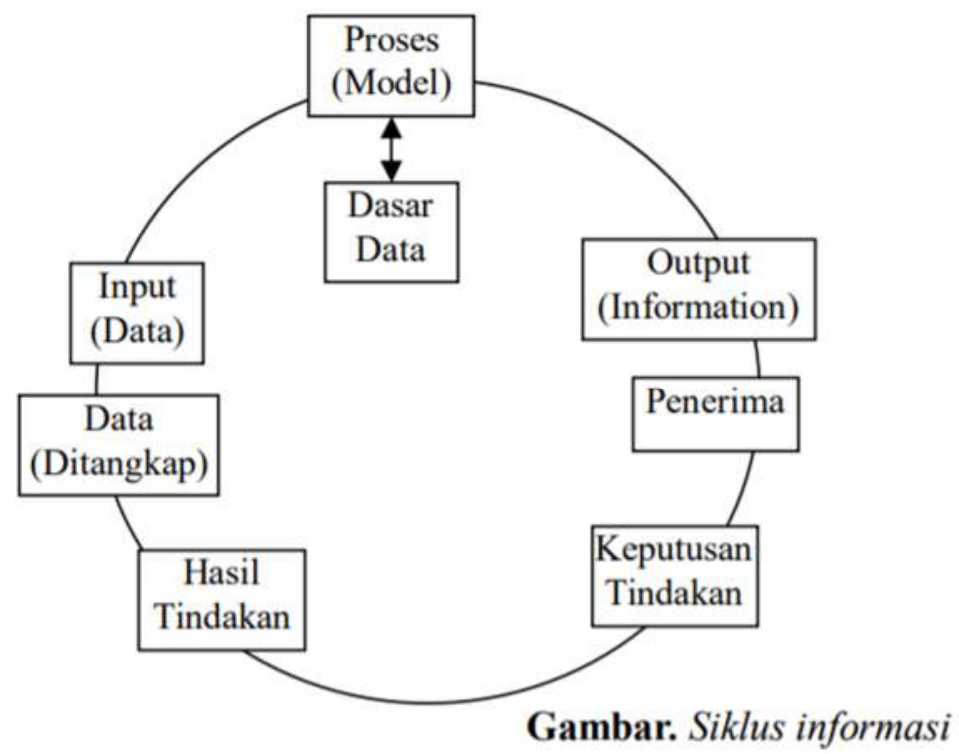

Informasi yang berkualitas tergantung pada 3 (tiga) hal yakni, relevan (relvance), tepat waktu (timesliner), dan informasi yang dibuat harus akurat (accurate). Informasi yang didapatkan juga harus berasal dari sumber yang valid. Hingga nantinya semua keputusan yang didapatkan dari informasi tersebut akan memudahkan suatu organisasi dalam mengambil keputusan yang sudah terstruktur.

Relevan, yakni informasi itu mempunyai manfaat bagi pemakainya. Relevansi informasi untuk setiap pengguna informasi yang satu dengan lainnya berbeda. Misalnya informasi mengenai harga pokok produksi untuk ahli Teknik perusahaan adalah kurang relevan dan akan lebih relevan untuk akuntan perusahaan.

Tepat waktu, yakni informasi yang datang untuk penerima informasi tidak boleh terlambat. Di era sekarang ini, informasi akan semakin mahal 
dikarenakan cepatnya informasi tersebut didapatkan, sehingga teknologi yang mutakhir diperlukan untuk mendapatkan, dan mengolah serta mengirimkannya. Infromasi yang sudah lama atau using tidak memiliki nilai lagi. Karena jika hal tersebut terjadi maka kemungkinan akan menyebabkan keterlambatan dalam pengambilan keputusan, sehingga akan berakibat fatal untuk suatu Lembaga atau organisasi.

Akurat, yakni informasi bebas dari semua kesalahan dan tidak boleh menyesatkan. Akurat juga berarti informasi harus jelas dan akurat karena dari sumber informasi sampai ke penerima informasi mempunyai kemungkinan banyak terjadi gangguan hingga dapat merubah ataupun merusak informasi tersebut.

Suatu Lembaga atau Organisasi pada dasarnya memiliki empat bagian penting yang harus dikelola dengan sebaik-baiknya. Bagian-bagian tersebut adalah Keuangan, Operasional, Pemasaran, dan Sumber Daya Manusia. Tiap bagian memiliki tanggung jawab serta fungsi yang berbeda-beda, tergantung tingkatan dan bentuk Lembaga atau organisasi tersebut.

Informasi memiliki fungsi utama yaitu mengurangi ketidakyakinan dan menambah pengetahuan pemakai informasi. Beberapa informasi tidak dapat diartikan nilai daya gunanya. Nilai informasi didasarkan atas sepuluh sifat, yakni :

a. Jelas

Memperbaiki laporan dapat memakan biaya yang besar. Sifat ini memperlihatkan informasi output yang tidak ada istilah yang aneh.

b. Teliti

Dalam hubungannya data yang besar biasanya muncul dua jenis kesalahan, yaitu kesalahan perhitungan dan pencatatan. Sifat ini memiliki hubungan dengan tingkat kebebasan dari kesalahan informasi output.

c. Tepat waktu

Di beberapa hal, ketepatan dapat diukur. Sifat ini berhubungan dengan waktu yang dilewati lebih singkat daripada cara untuk mendapatkan 
informasi. Pelaporan keluaran, masukan, dan pengolahan ke para pemakai harus tepat waktu.

d. Lengkap dan luas

Sifat yang memperlihatkan kelengkapan isi informasi. Tentang informasi output maupun volumenya. Sifat ini sulit diukur karena abstrak.

e. Mudah didapatkan

Menunjukkan cepat dan ketidaksulitan dalam mendapatkan informasi. Kecepatan saat memperolehnya dapat diukur, contohnya 2 menit versus 20 jam.

f. Kecocokan

Isi informasi harus mempunyai hubungan dengan problem yang dihadapi. Sifat ini memperlihatkan baik buruknya informasi output dengan permintaan pengguna informasi dalam hubungannya.

g. Memiliki bukti

Dapat menunjukkan kemampuan para pengguna informasi untuk membuktikan informasi output hingga pada kesimpulan yang sama.

h. Dapat diukur

Bisa menunjukkan dasar informasi yang didapatkan dari sistem informasi formal.

i. Luwes

Berkaitan dengan bisa disesuaikannya informasi output tidak dengan lebih dari satu keputusan namun juga dengan lebih dari satu seorang pengambil keputusan.

j. Tidak ada prasangka

Memiliki hubungan dengan tidak ada kemauan dalam mengubah informasi yang berguna untuk mendapatkan kesimpulan yang sebelumnya sudah diperhitungkan.

\section{Konsep Dasar Sistem Informasi Manajemen}

Biasanya, sumber daya yang tersedia dalam manajemen yaitu manusia, material, dan modal. Sistem informasi manajemen menurut Scott (1997) ialah 
"serangkaian sub-sistem informasi yang menyeluruh dan terkoordinasi dan secara rasional terpadu yang mampu mentransformasikan data sehingga menjadi informassi lewat serangkaian cara guna memingkatkan produktivitas yang sesuai dengan gaya dan sifat manajer atas dasar kriteria mutu yang ditetapkan." (hal. 100).

Sistem infromasi manajemen adalah sistem yang sudah dirancang untuk mengolah data menjadi sebuah informasi sehingga dapat membantu penggunanya untuk meningkatkan serta memperbaiki kualitas Lembaga atau Organisasi yang menjadi tanggung jawabnya, dan nantinya juga akan berguna dalam pengambilan suatu keputusan untuk mencapai tujuannya. Sistem Informasi Manajemen juga dapat membantu penggunanya dalam menjalankan fungsi-fungsi manajemen di dalam Lembaga atau Organisasi.

Jika suatu Lembaga atau Organisasi dapat mengelola sistem informasi manajemennya dengan baik maka akan bermanfaat bagi pemimpinnya, yakni dapat membantu melalui koordinasi yang baik dalam mengawasi, merencanakan, mendelegasikan, dan mengarahkan pekerjaan kepada semua anggotanya.

Karakteristik SIM :

a. SIM dibentuk untuk memberikan laporan operasional sehari-hari hingga akhirnya bisa memberi informasi untuk mengatur pengoperasian tersebut dengan lebih baik lagi.

b. SIM bergantung pada alur informasi yang ada di Lembaga atau Organisasi tersebut.

c. SIM membantu pemimpin Lembaga atau Organisasi dengan terstruktur pada perencanaan bagi anggota yang sudah senior, tingkat operasional dan tingkat kontrol.

d. SIM umumnya tidak dapat menganalisis masalah.

e. SIM umumnya tidak bersifat dapat menyesuaikan dikarenakan bentuk semua laporan yang telah dibuat sudah dirancang atau direncanakan sebelumnya. 
f. SIM butuh rencana yang sudah dibuat untuk waktu jangka Panjang dan sangat matang juga diikuti perhitungan perkembangan Lembaga atau Organisasi di waktu yang akan datang.

g. SIM lebih menyesuaikan data yang ada pada Lembaga atau Organisasi daripada data yang didapatkan diluar Lembaga atau Organisasi.

h. SIM umumnya juga melakukan penyesuaian dengan data yang telah terjadi dan yang sedang terjadi, tidak dengan data yang akan terjadi.

\section{METODE PENELITIAN}

\section{Pengambilan Keputusan}

Sebagian besar dari waktu, perhatian, ataupun pikiran seorang pemimpin digunakan untuk mempelajari permasalahan dan bagaimana solusi didalam Lembaga atau Organisasi dan akhirnya akan menentukan keputusannya. Maka semakin tinggi posisi seseorang di dalam Lembaga atau Organisasi, akan semakin berpengaruh pula keputusan yang menjadi tugas utama yang harus dilakukannya.

Pengambilan keputusan ialah hasil dari pemecahan masalah, jawaban dari suatu pernyataan sebagai hukum situasi, pemilihan dari salah satu alternatif yang ada, dan akhir dari proses pemikiran tentang masalah yang sedang dihadapi. Keputusan merupakan hasil akhir dari pengambilan keputusan.

Dalam penyelesaian masalah didalam Lembaga atau Organisasi, Sistem Informassi Manajemen memiliki peran yang dibagi menjadi tiga tahap.

a. Memilih pengujian kelayakan dari solusi atau pemecahan masalah yang melibatkan seleksi pelaksanaan dan arah tindakannya.

b. Menelusuri pemahaman masalah meliputi pengakuan adanya masalah dan usaha penyelidikan lingkungan.

c. Mendesain bentuk solusi atau pemecahan masalah meliputi penemuan alternatif pemecahan masalah, pengembangannya, dan analisis sebab akibatnya. 
Intinya, Sistem Informasi Manajemen bertugas sebagai penyaring informasi yang berdasarkan kepentingan Lembaga atau Organisasi untuk meningkatkan keedektifan pengambilan keputusan.

\section{Decision Support System}

Sistem pendukung pengambilan keputusan kelompok (DSS) adalah sistem yang membantu pengambil keputusan dalam menggunakan data melalui model yang dipakai untuk menyelesaikan masalah yang tidak terstruktur dengan berbasis komputer yang interaktif.

DSS dapat juga diartikan sebagai tambahan bagi pengambil keputusan untuk memeperluas ilmunya, tetapi tidak untuk menggantikan keputusannya. Cara kerja sistem pendukung ini dengan mengumpulkan data, semua model dan alat analisis, perangkat lunak ke dalam suatu sistem yang melekat dengan tampilan pengguna dan juga memiliki kekuatan besar yang dapat mendukung pengambilan keputusan.

Tujuan DSS yakni membantu pengambil keputusan dalam memecahkan masalah semi-terstruktur, mendukung dan bukan mengganti keputusan pengambil keputusan, meningkatkan daya guna pengambilan keputusan dan bukan kepraktisannya.

\section{Jenis-jenis DSS}

Jenis-jenis DSS menurut tingkat kerumitan dan tingkat dukungan pemecahan masalahnya menurut Steven L. Alter, 1976 adalah sebagai berikut :
a. Mengambil elemen-elemen informasi.
b. Menganalisis seluruh file.
c. Menyiapkan laporan dari berbagai file.
d. Memperkirakan dari akibat. Keputusan
e. Mengusulkan Keputusan
f. Membuat keputusan

\section{Komponen DSS}


a. Data Management. termasuk Database Management Systems (DBMS) yaitu data yang signifikan untuk berbagai situasi dan diatur oleh software.

b. Model Management. Dapat memberikan ke sistem manajemen software yang diperlukan dan suatu kemampuan analitis. Komponen ini menyertakan model finansial, management science, statistical, atau model kuantitatif lainnya.

c. Knowledge Management. Komponen ini dapat mendukung komponen yang lain ataupun sebagai komponen yang berdiri sendiri.

d. Communication (dialog subsystem). Pengguna software dapat memberikan perintah dan berkomunikasi antarmuka pada DSS melalui komponen ini.

\section{Dampak penggunaan DSS}

a. Meningkatkan control dan produktivitas dari manajer.

b. Dapat memberikan kesempatan bagi pengguna informasi untuk berkomunikasi dengan baik.

c. Mempunyai sistem yang bisa berinteraksi.

d. Dapat menyelesaikan masalah yang kompleks.

e. Dapat memberikan keputusan yang lebih efektif untuk masalah yang berulang.

f. Dapat menyelesaikan masalah semi-struktur.

g. Untuk menyelesaikan masalah yang dialami oleh manajer yang kurang berpengalaman, DSS dapat menghasilkan acuan data.

h. Pengambilan keputusan dengan DSS hasilnya lebih cepat dan baik daripada pengambilan keputusan dengan intuisi.

\section{PEMBAHASAN}

\section{Peranan SIM dalam pengambilan keputusan}

Pengambilan keputusan akan menjadi tugas utama seoran pemimpin jika tingkat kepemimpinannya semakin tinggi sehingga keputusan yang dibuat pun akan sangat berpengaruh besar bagi Lembaga atau Organisasi yang dipimpinnya.

Pengambilan keputusan memiliki tujuan, yakni : 
a. Memiliki sifat tunggal, yakni keputusan yang ada jika keputusan tersebut dibuat hanya untuk satu masalah dan tidak ada hubungannya dengan masalah yang lain.

b. Memiliki sifat ganda, yakni keputusan yang dibuat untuk mengatasi tidak hanya satu masalah, namun bisa untuk memecahkan ataupun mengatasi lebih dari satu masalah yang bersifat kontradiktif ataupun bersifat tidak kontradiktif.

Pengambilan keputusan terbagi menjadi 3 tipe, yaitu :

a. Keputusan terprogram/keputusan terstruktur, yakni keputusan berkala yang kemudian nanti akan diprogram. Umumnya, keputusan seperti ini dilakukan oleh manajemen tingkat bawah.

b. Keputusan setengah terprogram / setengah terstruktur, adalah keputusan yang sebagian bisa di program, sebagian lagi merupakan keputusan berkala dan juga ada keputusan yang membutuhkan pertimbangan serta perhitungan yang lebih rinci lagi. Keputusan ini dilakukan oleh manajemen tingkat menengah.

c. Keputusan tidak terprogram / tidak terstruktur, yakni bukan keputusan berkala dan tidak rutin terjadi. Dan biasanya keputusan ini dilakukan oleh manajemen tingkat atas.

\section{Pengambilan Keputusan Khusus}

Pengambilan keputusan khusus adalah penentuan keputusan opeerasi perusahaan yang bersifat khusus, tidak berkala, dan luar biasa. Contoh-contoh dari pengambilan keputusan khusus yaitu penambahan atau pengurangan jenis departemen atau produk, membeli dari luar atau membuat sendiri bahan baku produksi, menolak atau menerima penjualan pemesanan, memproses atau menjual lebih lanjut hasil produksi, dan memakai sendiri atau menyewakan atau menjual fasilitas perusahaan.

\section{Penerapan Decision Support System}

Sistem pendukung ini sudah banyak dipakai dan digunakan oleh Lembaga atau Organisasi yang besar. Ilmu dan keahlian yang ada pada DSS sangat banyak 
membantu Lembaga atau Organisasi yang menerapkannya untuk menciptakan koordinasi proses kegiatan dengan cara yang lebih tepat baik internal maupun eksternal.

Umumnya, agar dapat menentukan masalah dan mendapatkan solusi pemecahannya merupakan tujuan dari pengunaan informasi dari DSS bagi manager. Penentuan masalah dilakukan dari pendekatan sistem yang berkaitan dengan intelegensi seperti yang dikemukaan Simon. Yang nantinya manager akan memakai informasi agar dapat memecahkan masalah yang sudah dipelajari.

Kemudian dalam cara pencarian solusi sebuah masalah biasanya manajer akan menggunakan laporan rutin dan khusus. Laporan rutin dibuat bisa menjadi pengidentifikasian masalah yang berkesempatan besar akan timbul, yang lalu manajer juga akan meminta informasi kepada database agar mencari masalah yang telah diidentifikasi untuk dipelajari kembali.

Berikut beberapa penyebab DSS digunakan dalam suatu Lembaga atau Organisasi:

a. Perekonomian Lembaga atau Organisasi berjalan tidak stabil.

b. Lembaga atau Organisasi bersaing dalam kompetisi luar dan dalam negeri.

c. Kesulitan Lembaga atau Organisasi yang sedang mencari jumlah operasi bisnis.

d. Tidak adanya dukungan dari sistem komputer perusahaan dalam hal mencari jalan masuk di pasar yang menguntungkan, efisiensi dan profitabilitas.

\section{KESIMPULAN}

Dewasa ini, informasi dianggap telah mampu mengguncangkan berbagai bidang kehidupan manusia. Baik di bidang Ekonomi, Sosial, Budaya, maupun Ilmu Pengetahuan. Karena hal tersebut telah membuat perkembangan yang membawa era baru dari bidang-bidang tersebut.

Informasi sangat penting di dalam kehidupan manusia sekarang. Perkembangan zaman yang mana teknologi pun semakin canggih maka berkembang pula sebuah 
istilah Sistem Informasi Manajemen. Sudah jelas dari Namanya, sistem ini berperan penting dalam Lembaga atau Organisasi.

Suatu sistem pastinya memiliki sasaran (objective) atau tujuan (goal) yang akan sangat menentukan masukan dan keluaran yang dibutuhkan dan dihasilkan oleh sistem.

Informasi yang berkualitas tergantung pada 3 (tiga) hal yakni, relevan (relvance), tepat waktu (timesliner), dan informasi yang dibuat harus akurat (accurate). Informasi yang didapatkan juga harus berasal dari sumber yang valid. Hingga nantinya semua keputusan yang didapatkan dari informasi tersebut akan memudahkan suatu organisasi dalam mengambil keputusan yang sudah terstruktur. Informasi memiliki fungsi utama yaitu mengurangi ketidakyakinan dan menambah pengetahuan pemakai informasi. Beberapa informasi tidak dapat diartikan nilai daya gunanya.

Sistem informasi manajemen menurut Scott (1997) ialah "serangkaian sub-sistem informasi yang menyeluruh dan terkoordinasi dan secara rasional terpadu yang mampu mentransformasikan data sehingga menjadi informassi lewat serangkaian cara guna memingkatkan produktivitas yang sesuai dengan gaya dan sifat manajer atas dasar kriteria mutu yang ditetapkan." (hal. 100).

Sistem infromasi manajemen adalah sistem yang sudah dirancang untuk mengolah data menjadi sebuah informasi sehingga dapat membantu penggunanya untuk meningkatkan serta memperbaiki kualitas Lembaga atau Organisasi yang menjadi tanggung jawabnya, dan nantinya juga akan berguna dalam pengambilan suatu keputusan untuk mencapai tujuannya. Sistem Informasi Manajemen juga dapat membantu penggunanya dalam menjalankan fungsi-fungsi manajemen di dalam Lembaga atau Organisasi.

Jika suatu Lembaga atau Organisasi dapat mengelola sistem informasi manajemennya dengan baik maka akan bermanfaat bagi pemimpinnya, yakni dapat membantu melalui koordinasi yang baik dalam mengawasi, merencanakan, mendelegasikan, dan mengarahkan pekerjaan kepada semua anggotanya. 
Salah satu kegunaan Sistem Informasi Manajemen adalah dalam bidang Manajemen Sumber Daya Manusia. Menurut Rivai dan Ella (2009:521) banyak keputusan yang sehat didasari oleh adanya informasi yang benar dan berkualitas dari SDM. Jika menggunakan jaringan internet dan komputer, manajer SDM dan manajer lainnya bisa mengambil semua informasi yang bisa dipakai serta dibutuhkan dengan tujuan dalam pengambilan keputusan.

Tujuan pengelolaan Sistem Informasi Manajemen :

a. Membantu pimpinan Lembaga atau Organisasi dalam proses pengambilan keputusan sebagai penyedia informasi

b. Membantu pimpinan Lembaga atau Organisasi dalam menjalankan semua fungsi manajemen sebagai penyedia informasi

c. Membantu Lembaga atau organisasi dalam mewujudkna tujuannya dengan cara menjadi penyedia informasi yang dibutuhkan.

d. Serta dapat memperbaiki dan meningkatkan kualitas Lembaga atau Organisasi dengan cara menjadi penyedia informasi.

Dalam penyelesaian masalah didalam Lembaga atau Organisasi, Sistem Informassi Manajemen memiliki peran yang dibagi menjadi tiga tahap.

a. Memilih pengujian kelayakan dari solusi atau pemecahan masalah yang melibatkan seleksi pelaksanaan dan arah tindakannya.

b. Menelusuri pemahaman masalah meliputi pengakuan adanya masalah dan usaha penyelidikan lingkungan.

c. Mendesain bentuk solusi atau pemecahan masalah meliputi penemuan alternatif pemecahan masalah, pengembangannya, dan analisis sebab akibatnya.

\section{Dampak penggunaan DSS}

a. Meningkatkan control dan produktivitas dari manajer.

b. Dapat memberikan kesempatan bagi pengguna informasi untuk berkomunikasi dengan baik.

c. Mempunyai sistem yang bisa berinteraksi.

d. Dapat menyelesaikan masalah yang kompleks. 
e. Dapat memberikan keputusan yang lebih efektif untuk masalah yang berulang.

f. Dapat menyelesaikan masalah semi-struktur.

i. Untuk menyelesaikan masalah yang dialami oleh manajer yang kurang berpengalaman, DSS dapat menghasilkan acuan data.

j. Pengambilan keputusan dengan DSS hasilnya lebih cepat dan baik daripada pengambilan keputusan dengan intuisi.

\section{DAFTAR PUTAKA}

Bryan J. Kaleb, V. P. (2019). PENERAPAN SISTEM INFORMASI MANAJEMEN DAN PENGAWASANNYA DI KANTOR PELAYANAN PAJAK PRATAMA MANADO. Jurnal EMBA Vol.7 No. 1 Januari 2019, Hal. 781-790, 781-790.

Ike Susanti, I. K. (2020). PENERAPAN SISTEM INFORMASI MANAJEMEN PADA PENGAMBILAN KEPUTUSAN MANAJEMEN PT. JAYA BRIX INDONESIA DI LAMONGAN. Kompetensi, Vo 14, No 1, April $2020,27-35$.

Lipursari, A. (2013). PERAN SISTEM iNFORMASI MANAJEMEN (SIM) DALAM PENGAMBILAN KEPUTUSAN. JURNAL STIE SEMARANG, VOL 5, NO 1, Edisi Februari 2013, 26-37.

Paoki, R. (2012). PERAN SISTEM INFORMASI MANAJEMEN DALAM SEBUAH ORGANISASI. Jurnal Ilmiah Unklab, 78-85.

Peter. (2008). SISTEM INFORMASI KEUANGAN TERINTEGRASI DENGAN DUKUNGAN SISTEM PENGAMBILAN KEPUTUSAN (DSS) DALAM ORGANISASI. Jurnal Manajemen, Vol. 8, No. 1, November 2008, 68-72.

Ropal Tores, C. D. (n.d.). PERANAN SISTEM INFORMASSI DALAM MENINGKATKAN EFISIENSI DAN EFEKTIVITAS PENYIARAN DI RADIO DANGDUT INDONESIA (RDI) SEKAYU. 1-14.

Saliman. (2010). Mengenal Decisiom Support System (DSS). Vol. X No.1 Februari 201087 : 101, 87-101.

Sukma, P. I. (n.d.). PENTINGNYA IMPLEMENTASI SISTEM INFORMASI MANAJEMEN DALAM PENGAMBILAN KEPUTUSAN DI MANAJEMEN SEKOLAH. 1-5. 
Wahjono. (2014). PERANAN SISTEM INFORMASI DALAM PENGAMBILAN KEPUTUSAN MANAJEMEN. INFOKAM Nomor II / Th. IX/September / $14,46-52$.

ZULANDA, E. (n.d.). PERANAN PENERAPAN SISTEM INFORMASI MANAJEMEN DALAM MANAJEMEN SEKOLAH/PERGURUAN TINGGI. 1-8.

Fibriany, F. W. (n.d.). PENERAPAN SISTEM INFORMASI MANAJEMEN PADA PENGAMBILAN KEPUTUSAN DI DEPARTEMEN SDM. 1-4. 